\title{
An overview of Australian Water Resources Assessment reporting
}

\author{
Masoud Edraki, Ulrike Bende-Michl, Malcolm Watson, Rudi Van Den Bos, Falguni Biswas \\ The Australian Bureau of Meteorology \\ Email:m.edraki@bom.gov.au
}

\begin{abstract}
The Bureau of Meteorology, through the Water Act 2007, has been given responsibility for conducting regular assessments of Australia's water resources. This followed water reforms in Australia that were initiated in the 1990's with a focus on delivering efficient and sustainable use of water resources based on a thorough understanding of the Australian hydrological system and its spatio-temporal variability.

The 2012 Assessment is the second of the Bureau's regular series of such reports that combines observed data, outputs from a continental water balance model and advanced analytics to provide the status and conditions of use of the Australian water resource on a national scale as well as across 13 regions covering the whole of Australia. Much of the observed data used in the Assessments are provided to the Bureau under the Water Regulations 2008. The report supports informed decision making and dynamic management by policy-makers, water managers and planners of water in both the rural and urban sectors

This paper provides an overview of the 2012 Assessment. It presents highlights of the water situation in Australia including precipitation, evapotranspiration, landscape water yield, soil moisture, surface water storages and urban water use during the 2011-12 year (July-June) and compares them to the long-term record.
\end{abstract}

The paper also introduces strategies being implemented to stimulate the uptake of the assessment reports by stakeholders. The outcomes of a user response survey are presented in this regard.

Keywords: Landscape water balance, water resource assessment, stakeholder engagement 


\section{INTRODUCTION}

The establishment of the National Water Initiative in 2004 provided a blue print for water reforms in Australia. This followed by an ongoing drought which required improved water information and management of the nation's water resources.

As part of the water reform process the Bureau of Meteorology (the Bureau), through the Water Act 2007, has been given the responsibility of administering the Water Information Program. This is to collate information and assess and report on the availability, condition and use of water resources in Australia. This is aimed at informing public policy, programs and practices for better management of the nation's water resources.

The Australian Water Resources Assessments are regular reports that present information on the extent and magnitude of Australia's water resources. They provide assessment of climatic drivers, water flows and stores on the landscape at national and regional scales using a vast amount of data from various sources. These reports show recent anomalies and trends in the hydrological characteristics of rivers and aquifers at selected monitoring sites and water availability and use in some of the major cities and irrigation areas. The online publication of the reports includes supplementary technical information, a glossary and a summary report. All data used to produce the figures contained in the reports is available (electronically) with provision for downloading the data (and the supporting metadata).

The 2012 Assessment is the second of a series of reports that uses the data provided from various organisations across the country as well as the research outputs of the Bureau's Water Information Research and Development Alliance with the CSIRO. The report provides information on the climatic conditions, water stores and flows across Australia for the 2011-12 year.

This paper provides an overview of the structure of the report with sample results from the 2012 Assessment. The communication and adoption strategy of the Bureau which is aimed at increasing awareness and improving the quality of the product is also introduced.

\section{THE ASSESSMENT APPROACH}

\subsection{Reporting regions}

The reporting regions in the Assessments are derived from the Australian Hydrological Geofabric (Geofabric) product, which was developed by the Bureau in partnership with Geoscience Australia, the Australian National University and CSIRO (Bureau of Meteorology 2012). This product provides information on spatial relationships between important hydrologic features such as basins, rivers, water bodies, aquifers and monitoring points. The boundaries of the 13 regions (Figure 1) have been determined based on a drainage-enforced 9 second digital elevation model. For more information please refer to: http://www.bom.gov.au/water/geofabric.

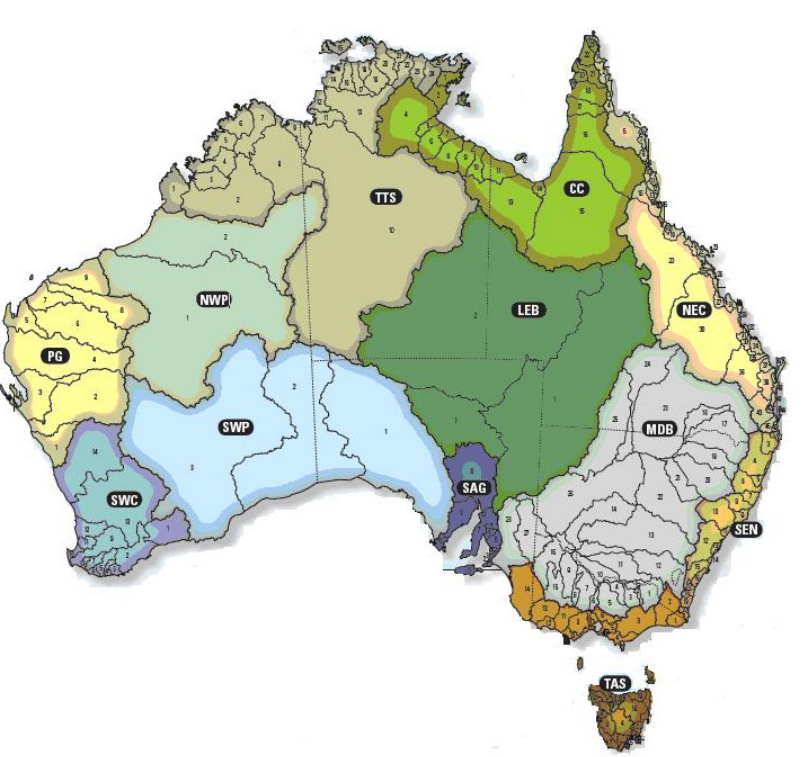

Figure 1. Assessment reporting regions. Full details in: http://www.bom.gov.au/water/geofabric/doc uments/BOM002_Map_Poster_A3_Web.pdf 


\subsection{Water balance framework}

The Assessments builds on a conceptual water balance framework of spatially distributed landscape water flows and stores for $5 \times 5 \mathrm{~km}$ grid cells across Australia. This includes actual evapotranspiration, landscape water yield and soil moisture which are calculated by the AWRA-L model (Van Dijk 2011). Other water balance terms that are included in the Assessments, such as interpolated rainfall, streamflow and water storage levels are derived from measured data.

\subsection{The national landscape water balance model}

The Australian Water Resources Landscape system (AWRA-L) is a grid-based distributed hydrological model that simulates water flows and stores at a daily time step. Its spatial resolution is defined by the resolution of daily precipitation grids $\left(0.05^{\circ}\right)$. Each grid cell contains one or more hydrological response units that represent shallowrooted and/or deep-rooted vegetation cover on which the water and energy flux simulations occur (Van Dijk 2010).

A simplified schematic of the water balance in the model is shown in Figure 2. After allowing for interception losses and surface runoff $\left(Q_{r}\right)$, the remainder of precipitation $(P)$ infiltrates into the shallow and deep soil layers to contribute to the soil storage $\left(S_{s}\right)$ where it is subjected to evaporation from the soil surface or transpiration from the vegetation.

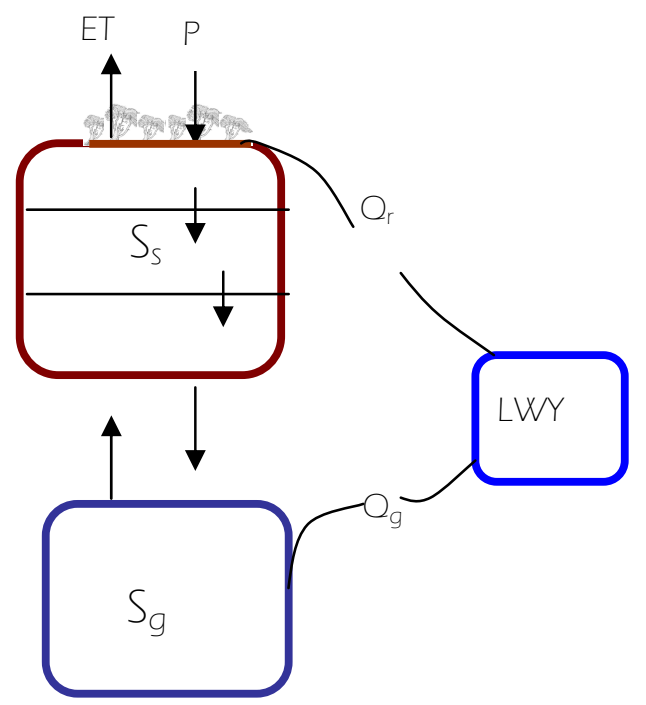

Figure 2. Schematic of water balance in AWRA-L

In the assessment, the latter two processes combined with intercepted evaporation losses are defined as evapotranspiration. Water may also drain from the deep soil layer to the groundwater storage $\left(S_{g}\right)$ and provide discharges to the surface water as baseflow $\left(Q_{g}\right)$.

A landscape water yield component (LWY) is determined by combining surface runoff and groundwater discharge (Figure 2). For model verification purposes the landscape water yield outputs of all grid cells in a catchment are combined to compare with streamflow at the outlet of the catchment.

\subsection{Measured data}

The observed water resources information used in the assessment report are currently obtained from various sources. For example, the streamflow and storages data are extracted from the Bureau's water information database where the Water Regulations information is stored. The information about urban population are obtained from the Australian Bureau of Statistics census data, and the water use data are extracted from the annual reports of the related agencies or through direct contact with the custodians of the information in the region. It is expected that more regulations data will gradually become available in the Bureau's water information system for the future assessment reports.

\subsection{National overview}

The National Overview presents water balance components across the nation. Daily rainfall, evapotranspiration, landscape water yield and soil moisture are aggregated to determine monthly and annual amounts. Deciles rankings of these terms for the reporting year are calculated with respect to the long-term record (1911-2012).

The changes in accessible total storage volumes in major public water storages in the 13 reporting regions are evaluated by aggregating and comparing to the preceding year. Similarly water supplies to the major cities for the reporting year are compared and presented against their historic values. Agricultural water use is estimated using information available for natural resource management areas in each reporting region. Groundwater levels in selected aquifer systems are assessed in terms of their trend over the past five years. 
Drivers of climatic conditions in the reporting year are discussed in terms of changes in the monthly time series of the Southern Oscillation Index (SOI) and the weekly time series of the Indian Ocean Dipole (IOD) over the preceding 5 years.

\section{REGIONAL CHAPTERS}

Regional chapters provide spatial and temporal analyses of the water resources.

\subsection{Modelled landscape water flows}

For each region, average monthly landscape water flows (rainfall, evapotranspiration and landscape water yield) for the reporting year are presented against their long-term (1911-2012) monthly distributions. Maps of decile rankings of landscape water flows for 2011-12 in comparison to the long-term records are provided along with an analysis of the trends in the landscape water flows for each grid cell since 1980.

\subsection{Measured data}

Example of measured data and methodologies employed for each are as follows:

- Average annual and summer streamflow discharge from selected monitoring sites in each region are presented together with their decile rankings for the 1980-2012 period. Other information related to streamflow in the region includes flood occurrence maps and annual streamflow salinity maps. Daily streamflow for upstream gauges of selected wetlands are ranked in decile classes for the daily data since 1980 and are shown as colour coded raster diagrams.

- Changes in groundwater level are presented by trend maps and hydrographs from selected bores.

- Time series of storage volume change over recent years is provided. The change in water restriction levels over time is also shown in relation to the associated combined storage volumes.

- Irrigation water use is presented at the Natural Resource Management level as maps and bar charts.

- Variation of shallow groundwater level and salinity is reported at selected bores in conjunction with rainfall cumulative residual and stream flow. The median groundwater level map for the reporting year and the decile ranking map of groundwater related to the preceding 20 years are also provided for aquifers in selected areas.

\section{THE 2012 ASSESSMENT}

This section provides highlights from some of the results in the National Overview as well as from a regional chapter of the 2012 assessment.

\subsection{Climatic drivers}

The Australian climatic condition during 2011-12 was characterised by a switch between neutral El Niño-

Southern Oscillation (ENSO) conditions during JulySeptember 2011 and a moderately strong La Niña event (the positive phase of ENSO as seen in Figure 3) in spring 2011 which led to the third wettest March on record.

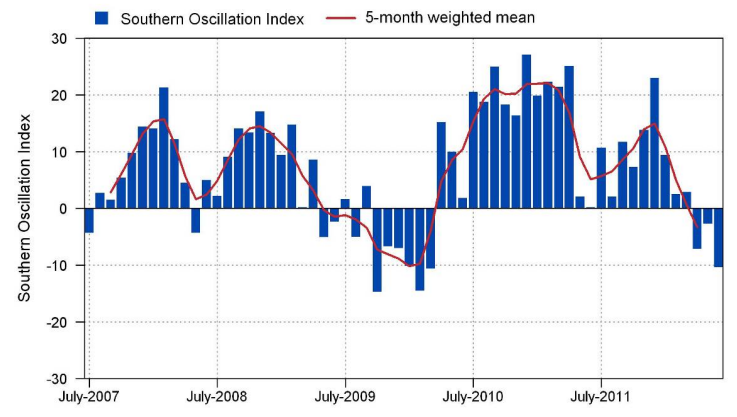

Figure 3. Seasonal changes in Southern Oscillation Index since 2007

\subsection{Landscape water flows}

The climatic drivers caused markedly above average rainfall across the majority of the continent, most of which fell between November 2011 and March 2012. It caused widespread flooding events, especially in the South East Coast (NSW) and Murray-Darling Basin, North East Coast and Lake Eyre Basin regions. A 
localised rainfall event in June 2012 caused extensive flooding in eastern parts of the South East Coast (Victoria) region.

Elevated rainfall further increased high soil moisture content, particularly across the southeast of the country. This resulted in above average evapotranspiration and landscape water yield conditions. An exception to this was the South West Coast region where soil moisture conditions increased only marginally and remained below long-term average levels (Figure 4).

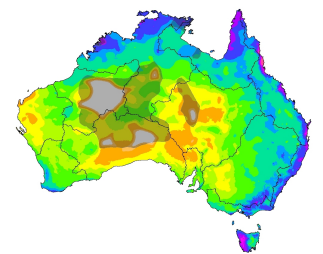

a

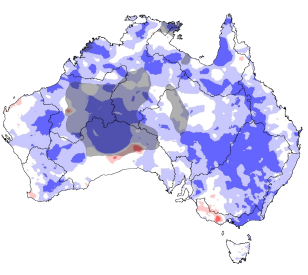

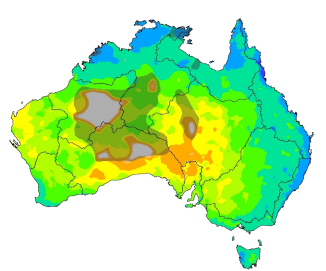

b

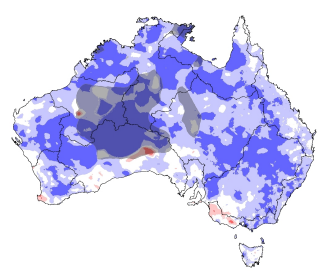

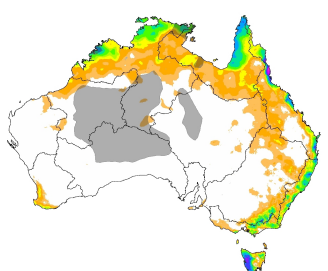

c

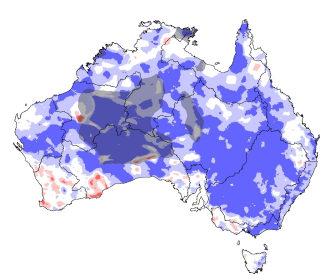

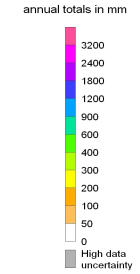

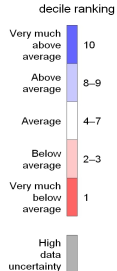

Figure 4. Landscape water flow components and their deciles during 2011-12: a) rainfall, b) evapotranspiration and c) landscape water yield.

The above average streamflow conditions in large parts of the country resulted in substantial storages inflows. The increase in storage levels was particularly high in the Murray-Darling Basin and Tasmania.

\subsection{Groundwater}

Groundwater levels during the 2007-2012 period showed rising trends in most of the analysed shallower aquifers within the North East Coast, South East Coast (Victoria) and Murray-Darling Basin regions. Trends in groundwater levels in the South Australian Gulf region were more variable, reflecting responses to the local groundwater extraction and rainfall events (results not shown here).

\section{REGIONAL ASSESSMENTS (MDB REGION EXAMPLE)}

The annual average soil moisture conditions in the Murray-Darling Basin for 2011-12 are shown in Figure 5. Conditions were very much above the average for the majority of the region. This was due to high antecedent soil moisture as well as high rainfall.
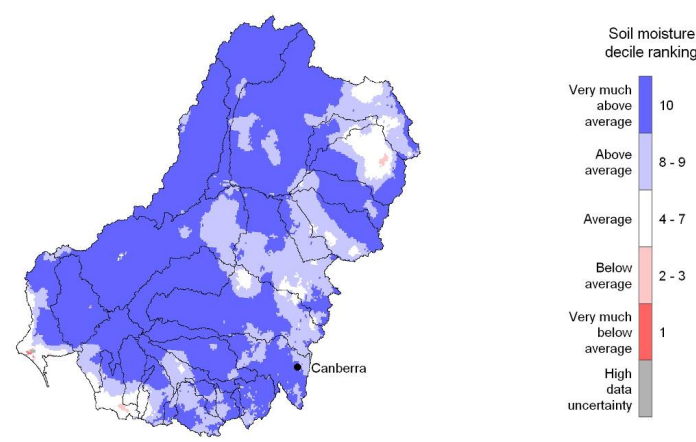

Figure 5. Deciles rankings of annual average soil moisture for 2011-12 in comparison to the 19112012 period of the Murray-Darling Basin region 
Continuing from the relative wet year in 2010, the irrigation storage capacities in this region filled up further or remained at their high levels (Figure 6). Increased water availability favoured expansion of cropping in the irrigation areas.

The above average rainfall of the past two years in the ACT saw an easing of water saving measures that were introduced in response to the millennium drought. Figure 7 illustrates the urban water use restriction measures for Canberra and Queanbeyan since 1999 in response to water volumes in the storages. For the first time in October 2003, the highest restriction level was introduced and was repeated for an extended period between December 2006 and October 2010. Permanent water conservation measures were introduced in March 2006 and were put in place again in November 2010 despite high levels of water storage volumes

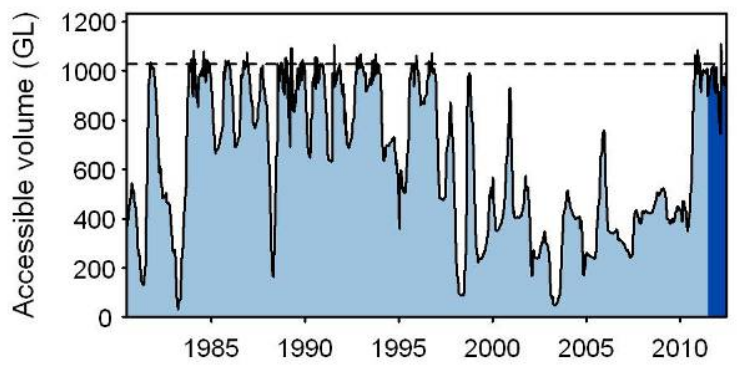

Figure 6. Water storage volumes available for irrigation at the Burrinjuck storage since 1980

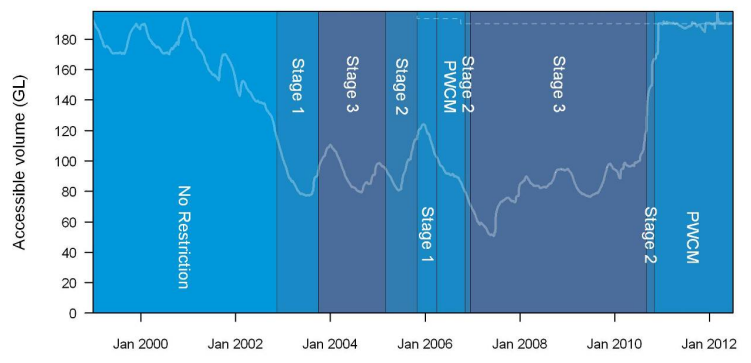

Figure 7. Urban water use restrictions and water storage levels (1999-2012) for the combined accessible water volumes of Googong and Corin storages

\section{STAKEHOLDER ENGAGEMENT}

As the Assessments are intended to increase the awareness of water resources in Australia, particularly for policy specialists and water resource managers, a stakeholder engagement strategy is in place. The aims of this strategy are to:

- ensure that water planners, policy-makers, key water users and other stakeholders in Australia are aware of the reports;

- demonstrate the value and benefits of the reports to the key users;

- engage potential users in the reports and motivate them to use the reports on a regular basis;

- engage with stakeholders to receive feedback and to target further user needs on water resource information; and

- identify and manage risks and issues that may arise from the communication and adoption process.

In practice this strategy so far resulted in the following activities:

\section{- Receiving feedback to enhance the quality of assessment reports}

A user response survey was conducted after the release of the 2010 Assessment. The purpose was to receive guidance for future improvements to the product and to receive feedback on how the assessment is being, or might be, used and how it might be made more useful in future. A wide range of users and potential users of the report from Commonwealth, State and regional agencies were selected for the survey. Some of the key survey findings and provided recommendation were to (i) increase the awareness of the report, (ii) provide information on water quality and increase the coverage of groundwater information (iii) include additional regionalisation to the level at which water resource management plans are currently made (e.g. catchment level). These recommendations are being taken into consideration for future reports.

Technical feedback is also received on drafts of the reports. State and Territory water agencies, academic representatives and professional service organisations provide valuable feedback while the reports are being 
prepared for publication. This feedback has served to improved the consistency, messaging and presentation of the report

\section{- Activities to increase the awareness, demonstrating the value and use of the report}

The assessments are available through the Bureau's website. Information is also presented providing examples how the report can be used. Stakeholders are informed when new reports are released and presentations are arranged at various venues.

\section{CONCLUSIONS}

The purpose of the Bureau of Meteorology's Water Resource Assessments is to provide improved information for the development of public policies, programs and practices for better management of water resources in Australia. The reports provide analyses of national and regional water resources using both modelled and measured information on key water flows. The modelled information shows short term and long term patterns in landscape water flows for the nation and assessment regions. Information in the regional chapters such as those for cities and towns, agriculture, rivers and wetlands are largely based on data obtained from measured and gauged sites.

Australia experienced wet climatic conditions during the 2011-12 assessment year. This caused major floods especially in the southeast of Australia and resulted in all landscape water flows exceeding their long-term averages in most parts of the country. Due to increased storage volumes, the water available for urban and agricultural areas increased and similar to the previous year the water restrictions in major cities were eased.

The Bureau is engaging with its stakeholders to obtain feedback on the assessment report. This is to ensure that the key water users and policy makers are finding the product useful and, more importantly, that their feedback can be incorporated for improvement of the product.

\section{ACKNOWLEDGEMENT}

The assessment report is produced by various teams in the Water Resources Assessment section of the Bureau of Meteorology. These include the Urban, Rural and Water quality and trends units. The work and contribution of all individuals in the respected units are acknowledged. The authors wish to thank external agencies and individuals, the WIRADA project team and our colleagues in the Bureau of Meteorology who have assisted in preparation and review of the assessment reports.

\section{REFERENCES}

Bureau of Meteorology (2012) Topographic Drainage Divisions and River Regions http://www.bom.gov.au/water/about/riverBasinAuxNav.shtml\#a

Van Djik, A. (2010).The Australian Water Resources Assessment System. Technical Report 3. Landscape Model (version 0.5) Technical Description. CSIRO National Research Flagships. Water for Healthy Country. 